\title{
Nasopharyngeal Cancer Pathologic Regional Lymph Nodes TNM Finding v8
}

National Cancer Institute

\section{Source}

National Cancer Institute. Nasopharyngeal Cancer Pathologic Regional Lymph Nodes

TNM Finding v8. NCI Thesaurus. Code C132803.

A pathologic finding about one or more characteristics of nasopharyngeal cancer,

following the rules of the TNM AJCC v8 classification system as they pertain to staging of regional lymph nodes. 